\title{
Bat diversity from the Río La Novia Conservation Concession, Ucayali, Peru
}

\author{
Diversidad de murciélagos de la Concesión para Conservación Río La Novia, Ucayali, Perú
}

\section{Dennisse Ruelas ${ }^{1 *}$, Víctor Pacheco ${ }^{1,2}$, Nadia Espinoza ${ }^{1}$, and Christian Loaiza ${ }^{1}$}

\author{
* Autor para correspondencia \\ E-mail Dennisse Ruelas: dennisse.ruelas@unmsm.edu.pe \\ E-mail Víctor Pacheco: vpachecot@unmsm.edu.pe \\ E-mail Nadia Espinoza: ncelujan@gmail.com \\ E-mail Christian Loaiza: christian.loaiza@unmsm.edu.pe
}

1 Universidad Nacional Mayor de San Marcos, Museo de Historia Natural, Av. Arenales 1256, Lima 11, Perú.

2 Universidad Nacional Mayor de San Marcos, Facultad de Ciencias Biológicas, Instituto de Ciencias Biológicas "Antonio Raimondi”.

\begin{abstract}
Purús is a Peruvian Amazonian province with little information on its biodiversity, especially on small mammals. This work aims to document the bats diversity in the region by developing intensive inventories at the Río La Novia Conservation Concession, located on the right bank of the La Novia River, Purús, Ucayali Department. We surveyed the study area in the wet and dry seasons of 2015 using mistnets set on the ground and canopy, achieving a total sampling effort of $725 \mathrm{NN}$ (12-m mist nets/night). As result, we recorded 32 bat species that include four new records for Purus province, and two new records for the Ucayali department (Eumops cf. delticus and Molossops temminckii). The seasonal accumulation curves were adjusted to the Clench model; however, the asymptotes were not reached, suggesting that more fieldwork is needed. Non-surprisingly, Phyllostomidae was the most diverse family (24 species). Also, we found that Carollia perspicillata and Artibeus planirostris have the higher relative abundance and that the frugivorous bats were the most abundant trophic guild. Our results suggest that the abundance and composition of bats in the Río La Novia are probably related to seasonal changes, as seen in other primary forests. Considering that Purús maintains one of the few pristine forests in western Amazonia, we suggest that more surveys are needed for a better understanding of bat's diversity and bat assemblage patterns in tropical forests.
\end{abstract}

Keywords: primary forest; biodiversity; bats; Eumops; Molossops; Amazonian forests; Purús forests.

\section{Resumen}

Purús es una de las provincias de la Amazonía peruana con poca información sobre su biodiversidad, principalmente sobre los mamíferos pequeños. Este trabajo tiene como objetivo documentar la diversidad de murciélagos en la región mediante el desarrollo de inventarios intensivos en la Concesión de Conservación Río La Novia, localizada en el margen derecho del río La Novia, Purús, departamento de Ucayali. Realizamos evaluaciones de campo en temporada seca y húmeda del 2015, empleamos redes de neblina en subdosel y sotobosque, logrando un esfuerzo de muestreo total de 725 redes/noche. Como resultado, registramos 32 especies, que incluyen cuatro nuevos registros para Purús, de los cuales dos son nuevas para Ucayali (Eumops cf. delticus y Molossops temminckii). Las curvas de acumulación de especies por temporada se ajustaron al modelo de Clench; sin embargo, no se alcanzó la asíntota en ninguna, sugiriendo que más trabajo de campo es necesario. La familia mejor representada fue Phyllostomidae (24 especies), Además, encontramos que Carollia perspicillata y Artibeus planirostris fueron las especies más abundantes y que el gremio de los frugívoros fue el mejor representado. Nuestros resultados sugieren que la abundancia y composición de murciélagos en el Río La Novia están probablemente relacionados a los cambios estacionales, similar a otros bosques primarios. Debido a que Purús mantiene uno de los pocos bosques prístinos en el oeste de la Amazonía, sugerimos que más estudios son necesarios para conocer la diversidad y los patrones del ensamblaje de murciélagos en bosques tropicales.

Palabras clave: bosque primario; diversidad; murciélagos ; Eumops; Molossops; bosque amazónico; bosques de Purús.

Citación:

Ruelas D., V. Pacheco, N. Espinoza \& C. Loaiza. 2018. Bat diversity from the Río La Novia Conservation Concession, Ucayali, Peru. Revista peruana de biología 25(3): 211 - 220 (Agosto 2018). doi: http://dx.doi. org/10.15381/rpb.v25i3.14091

Funding: This study was founded by Travel Grants of World Wildlife Peru: TD 10 - TD 16, TD 96 - TD 99, TE 01 and TE 02

\section{Presentado: $\quad 30 / 12 / 2017$

Aceptado: $\quad 25 / 04 / 2018$

Publicado online: 25/09/2018

\section{Author contributions:}

DR designed the research, collected the specimens, analyzed the data and drafted the article. VP contributed in the collection of specimens, research design, data analysis, and critically reviewed the draft. NE contributed in the collection of specimens, photo edition, measuring specimens and reviewing the draft. CL contributed in the collection of specimens and reviewing the draft. All authors approved the final draft.

There is no conflict of interest among the authors.

Research permit:

Resolución de Dirección General N 0125-2015-SERFOR-DGGSPFFS

Journal home page: http://revistasinvestigacion.unmsm.edu.pe/index.php/rpb/index

(c) Los autores. Este artículo es publicado por la Revista Peruana de Biología de la Facultad de Ciencias Biológicas, Universidad Nacional Mayor de San Marcos. Este es un artículo de acceso abierto, distribuido bajo los términos de la Licencia Creative Commons Atribución-NoComercial-Compartirlgual 4.0 Internacional.(http://creativecommons.org/licenses/by-nc-sa/4.0/), que permite el uso no comercial, distribución y reproducción en cualquier medio, siempre que la obra original sea debidamente citadas. Para uso comercial, por favor póngase en contacto con editor.revperubiol@gmail.com. 


\section{Introduction}

In Peru, no less than 180 bat species have been recorded, representing more than $30 \%$ of the Peruvian mammalian species (Pacheco V. pers. comm.); and this richness is more concentrated in the Peruvian Tropical lowland forest (Pacheco 2002, Pacheco et al. 2009). The Ucayali Department is covered with extensive area of lowland forest and has a record of more than 87 bat species (Quintana et al. 2009, Medina et al. 2016); however, most of the territory is still unexplored, especially near the frontier with Brazil, in the Purus province.

The first expeditions to study the diversity of Purus were conducted in Balta, at the left bank of Río Alto Purus, between 1963 and 1971 by J. O’Neil, A. L. Gardner, and J. L. Patton, who recorded 130 species of mammals, including 56 bats (Voss \& Emmons 1996). Later, other studies in the province focused on large mammals (INRENA 2001, ADAR 2002, Leite et al. 2003, Lleellish et al. 2003, Pacheco \& Amanzo 2003, Ruelas et al. 2016a) and non-volant small mammals (Leite et al. 2003, Ruelas et al. 2016b). Unfortunately in the last 45 years, few studies on bat diversity were conducted (Voss \& Emmons 1996).

The main objective of this study was to study the diversity (species richness) and the relative abundance of bats from the Río La Novia Conservation Concession (RLN), located on the right margin of the Purús River (Ucayali, Perú), to compare it with other regions in the Peruvian Amazonia, and to support the efforts on the conservation and the sustainable use of biodiversity in this area.

\section{Materials and methods}

The Río La Novia Conservation Concession (RLN) is on the right bank of Río La Novia, a tributary of Purús River, in Purús district and province, Ucayali department, Peru (9 $50^{\prime} 42^{\prime}$ 'S, $70^{\circ} 41^{\prime} 42^{\prime} \mathrm{W}$, elevation $281 \mathrm{~m}$ ). The RLN is managed by the Asociación de Manejo y Conservación de Bosques Sin Fronteras (MABOSINFRON) created by residents of Puerto Esperanza, Purús (Fig. 1).

La Novia River area is a primary and dense forest with low human intervention with a very high canopy (20 to $30 \mathrm{~m}$ high) and abundant timber trees such as "Cedro" (Cedrela odorata), "caoba" (Sweitenia macrophyla), "ishpingo" (Amburana cearensis), "estoraque" (Myroxylon balsamun), "copaiba" (Copaifera paupera), and "azúcar huayo" (Hymenaea courbaril) (Cornejo 2016, Mena 2016). The area presents numerous hills and streams, with gentle and steep slopes, up to $75^{\circ}$ of tilt (Ruelas D. pers. obs.). The soil is mostly clay. In the dry season, La Novia river dries almost completely, the water level drastically from 3 or $2 \mathrm{~m}$ (wet season) until 0.10 to $0.50 \mathrm{~m}$ (Ruelas D. pers. obs.).

We conducted two surveys, in wet season (April - May 2015) and dry season (July - August 2015). In each survey, we installed

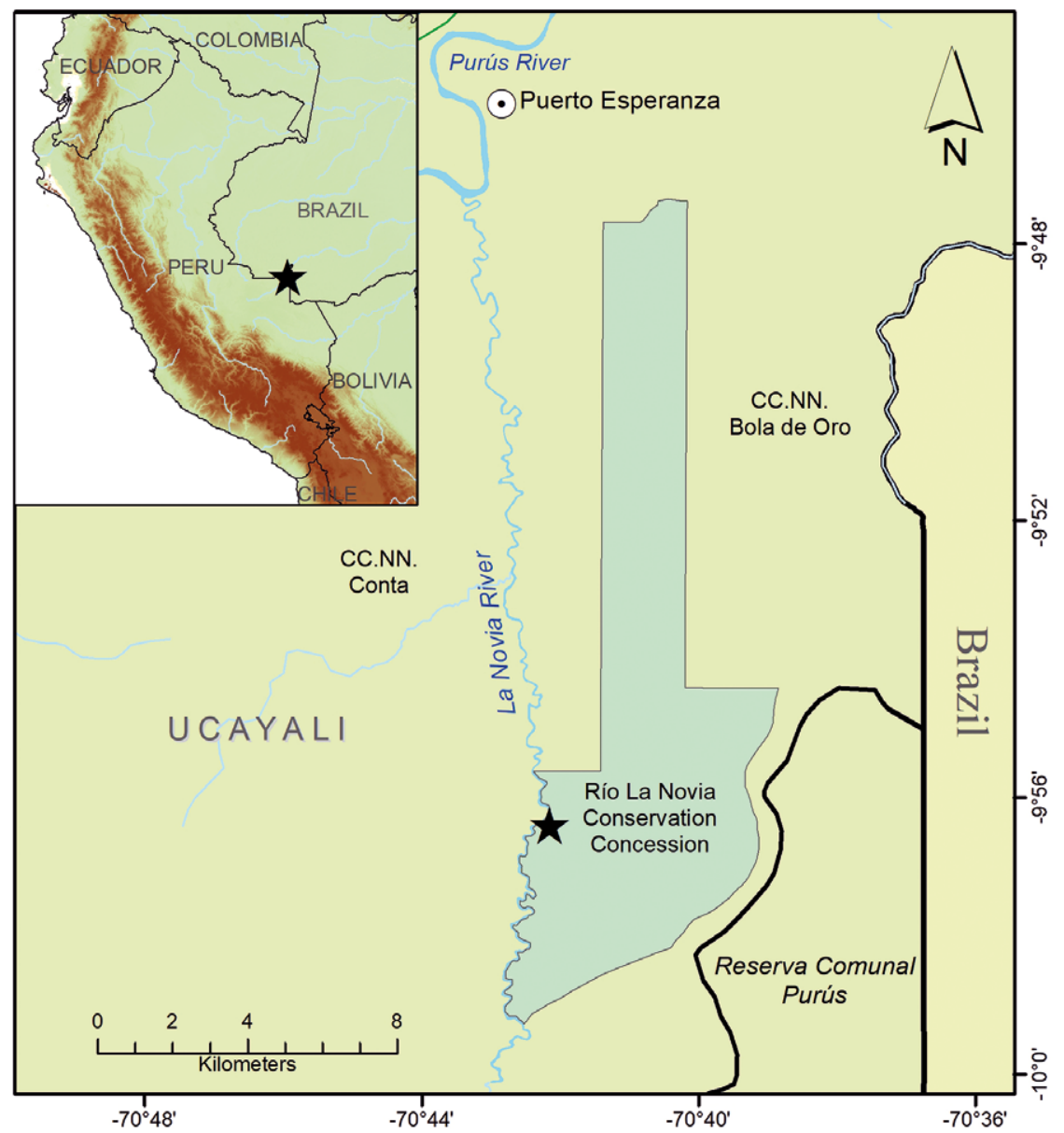

Figure 1. Map of Río La Novia Conservation Concession, the study area is shown with a black star, a projection is shown on the upper left edge. 
13 mist nets $(12 \times 2.5 \mathrm{~m}), 6$ on the ground and 7 at canopy level (approximately to $15 \mathrm{~m}$ high). Mist nets were active during 24 nights in the wet season and 27 nights in the dry season, from 18:00 to 00:00 hours. Captured bats were placed in cloth bags. We followed the ethical guidelines of the American Society of Mammalogist for the euthanasia of specimens (Sikes et al. 2016). We recorded the standard biometrical measurements, sex, and reproductive condition. Some specimens were fixed in $10 \%$ formalin for seven days, then washed with water and preserved in alcohol at $70^{\circ}$ (Kingston 2016). Other individuals were preserved as dry skins. We removed the skulls of specimens in the field, then cleaned at the lab using a dermestid colony. All specimens are deposited in the Museo de Historia Natural of the Universidad Nacional Mayor de San Marcos (MUSM).

For the taxonomic determination, we followed taxonomic keys (Gardner 2008, Diaz et al. 2016), revisions (Barquez et al. 1999, Woodman \& Timm 2006, Garbino et al. 2012, Ruelas 2017), and the specimens of the MUSM collection for comparisons. The taxonomic nomenclature used by Pacheco et al. (2009) was complemented with more recent taxonomic changes (Parlos et al. 2014). In addition, species representing new records were compared using diagnostic morphological characters and measurements available in the literature. We took the measurements of the specimens using a Mitutoyo caliper (Error: $\pm 0.01 \mathrm{~mm}$ ).

Sampling effort was expressed as mist nets-night:

$$
N=N^{\circ} \text { mist nets }{ }^{*} N^{\circ} \text { nights }
$$

Accumulation curve was estimated for each season by Clench model with the formula

$$
v 2=\left(a^{*} v 1\right) /\left(1+\left(b^{*} v 1\right),\right.
$$

where $a$ is the rate of increase of new species at the start of the sampling, and $b$ is the parameter related to the shape of the curve (Jimenez-Valverde \& Hortal 2003). To estimate the parameters of the curve, we used Estimates v. 9 software, and to make the graphics, we used Statistica v. 13 software. According to this model, the probability of adding species to the list decreases when sampling effort increase (Moreno 2001).

We determinate the relative abundance (RA) in relation to the sampling effort, which was expressed as individuals per mist net-night (ind/NN) (Pucek 1981, Pacheco et al. 2007). To estimate the accumulation curve and RA, we only included the individuals captured by mist nets. Other types of records were considered occasional.

We assigned species to trophic guilds following Emmons and Feer (1999) and Wetterer et al. (2000), and the percentage of each guild was calculated by dividing the number of individuals recorded of the guild " $\mathrm{n}$ " by the total of individuals recorded (Hice et al. 2004). For species with several trophic guilds, we considered only the most important, following Emmons and Feer (1999) and Wetterer et al. (2000).

In addition, we evaluated the similarity between Purús and other Amazonian forests using the Sorensen index and test whether this similarity is correlated with linear geographic distances using a Mantel test (Mantel 1967). We selected seven Peruvian Amazonian places considered well-inventoried for bats with records below $500 \mathrm{~m}$ of elevation. These were: Cusco Amazónico (Voss \& Emmons 1996), Centro de Investigacio- nes Jenaro Herrera (Ascorra et al. 1992, Fernández-Arellano \& Torres-Vásquez 2013), Reserva Nacional Matsés (Fleck et al. 2002), Parque Nacional Allpahuayo-Mishana (Hice et al. 2004, Diaz 2011), Reserva de Biósfera del Manu (Solari et al. 2006), Iquitos (Angulo \& Diaz 2004, Willig et al. 2007, Diaz 2011, Rengifo et al. 2013) and Parque Nacional Sierra del Divisor (Medina et al. 2015). For this purpose, the Purús bat list includes the records from Balta (Voss \& Emmons 1996) and RLN (this study).

We used R v.3.3.0 (R Core Team 2016) with the packages Vegan and Fossil (Oksanen 2015, Vavrek 2015). The linear geographic distances between areas were estimated in Google Earth. The level of statistical significance was $\mathrm{p}<0.05$.

\section{Results}

Richness species.- We gathered a total sampling effort of $725 \mathrm{NN}$ (334 NN in the wet season and $391 \mathrm{NN}$ in the dry season) in the RLN (Table 1). With this effort, we recorded 30 species of bats. Phyllostomidae was the most diverse family (24 species), followed by Molossidae (2 species) and Vespertilionidae (3 species), and finally the Emballonuridae (1 species). In addition, two occasional records were recorded in roosting in the wet season: 1) Peropteryx macrotis, six individuals found in a fallen tree, and 2) Molossus molossus, one individual, found in a house at Puerto Esperanza, $15 \mathrm{~km} \mathrm{~N}$ from the RLN. We did not include these specimens in the accumulation curve and the analysis of abundance. We also captured a female adult of Sturnira sp., apparently S. lilium, which was accidentally released before identification. In total, we report 32 bat species for RLN. In the appendix 1 some species from RLN are shown.

The species Phylloderma stenops, Peropteryx macrotis, Eumops cf. delticus, and Molossops temminckii were new additions for Purús. The last two species were captured with mist nets set up at about $15 \mathrm{~m}$ above the ground and are also the first records for the Ucayali department and represent a significant extension from their previous distributional range. The record of $E$. cf. delticus is also the second to Peru (Fig. 2, Table 2).

\section{FAMILY MOLOSSIDAE}

\section{Eumops cf. delticus Thomas, 1923}

Specimens examined: One male subadult collected in the wet season (MUSM 44156), and one female adult collected in the dry season (MUSM 44455), both collected at subcanopy level (Fig. 2, Table 2).

Remarks: The specimens of this species are characterized by the following characters corresponding the ones described for the species by Barquez et al. (1999): small size (Forearm length: $47.40-49.30 \mathrm{~mm}$ ), brown dorsal pelage, belly paler than the back, tail protruding from the uropatagium at least half of its length, rostrum slightly naked, pointed muzzle, smooth lips without pronounced folds, thick ears, rounded and widely separated in the crown, inner ear keel ends up behind the posterior border of the antitragus, sagittal and lambdoid crest poorly developed, basisphenoid pits moderately deep and rounded. The morphological differences among our specimens are probably related to sexual dimorphism or age as size and developed of lambdoid ridge. In Peru, this species was first reported from Iquitos, Loreto (Diaz 2011). This species also occurs in Colombia 
and Brazil. Its natural history, distribution and morphological differentiation is poorly known (Eger 2008).

\section{Molossops temminckii (Burmeister, 1854)}

Specimen examined: One male adult collected in the dry season (MUSM 44456), captured at the subcanopy level near to a small stream (Fig. 2, Table 2).

Remarks: Following Eger (2008) and by comparison with specimens of the MUSM mammal collection, this species is characterized by a small size (Forearm length: $31.30 \mathrm{~mm}$ ), dark brown dorsal pelage and belly paler than the back, dorsal fur with pale base, at least half the length of the tail free, naked rostrum, triangular ears with slightly rounded tips and widely separated in the crown, pointed muzzle, smooth lips without folds, the upper lip tilted backwards coinciding with the lower lip. In Peru, M. temminckii is known only from two localities in Loreto: Curaray River mouth (AMNH 71634, Eger 2008), and Reserva Nacional Allpahuayo-Mishana (Hice et al. 2004). An additional specimen was found in the MUSM collection from Flor de Yarina, Samiria River, Loreto collected by V. Pacheco on August 2, 1980 (MUSM 799). This species also occurs in Colombia, Venezuela, and Guyana, southwestward through Ecuador, Bolivia, Paraguay, and Brazil, into Uruguay and northern Argentina (Eger 2008). This bat uses human

Table 1. Species richness and relative abundance of bats from the RLN. Trophic guild: C: carnivorous, F: frugivorous, I: insectivorous, $\mathrm{N}$ : nectarivorous, $\mathrm{H}$ : hematophagous. The main guild is shown before the parentheses. Relative abundance: WS = wet season, DS $=$ dry season. New records: ${ }^{a}=$ for Purús, ${ }^{b}=$ for Ucayali.

\begin{tabular}{|c|c|c|c|c|}
\hline \multirow{2}{*}{ Family / Species } & \multirow{2}{*}{ Guild } & \multicolumn{2}{|c|}{ Relative abundance } & \multirow{2}{*}{ Vouchers (MUSM) } \\
\hline & & WS & DS & \\
\hline \multicolumn{5}{|l|}{ Emballonuridae } \\
\hline Peropteryx macrotis ${ }^{a}$ & I & & & $44151-44154$ \\
\hline Saccopteryx bilineata & I & 0.31 & & 44155 \\
\hline \multicolumn{5}{|l|}{ Phyllostomidae } \\
\hline Artibeus anderseni & $\mathrm{F}$ & & 0.51 & 44473,44474 \\
\hline Artibeus lituratus & $\mathrm{F}(\mathrm{I}, \mathrm{N})$ & & 0.26 & 44458 \\
\hline Artibeus obscurus & $\mathrm{F}(\mathrm{I}, \mathrm{N})$ & 1.88 & 3.58 & $44157-44162,44459-44465$ \\
\hline Artibeus planirostris & $\mathrm{F}(\mathrm{I}, \mathrm{N})$ & 1.56 & 2.30 & $44163-44167,44466$ \\
\hline Carollia benkeithi & $\mathrm{F}(\mathrm{I}, \mathrm{N})$ & 0.31 & & 44168 \\
\hline Carollia brevicauda & $\mathrm{F}(\mathrm{I}, \mathrm{N})$ & 0.31 & 0.77 & $44467-44469$ \\
\hline Carollia perspicillata & $\mathrm{F}(\mathrm{I}, \mathrm{N})$ & 4.69 & 1.28 & $44170-44184,44469-44471$ \\
\hline Chiroderma trinitatum & $\mathrm{F}(\mathrm{I}, \mathrm{N})$ & 0.31 & & 44185 \\
\hline Chiroderma villosum & $\mathrm{F}(\mathrm{I}, \mathrm{N})$ & 0.63 & 0.26 & $44186,44187,44472$ \\
\hline Desmodus rotundus & $\mathrm{H}$ & 0.31 & & 44188 \\
\hline Glossophaga soricina & $\mathrm{N}(\mathrm{I}, \mathrm{F})$ & 2.50 & 0.26 & $44189-44196,44475$ \\
\hline Hsunycteris thomasi & $N(I, F)$ & 1.25 & & $44197-44200$ \\
\hline Lophostoma silvicolum & $\mathrm{I}(\mathrm{F}, \mathrm{N})$ & 0.31 & & 44201 \\
\hline Mesophylla macconnelli & $\mathrm{F}(\mathrm{I}, \mathrm{N})$ & 0.31 & 0.26 & 44202,44476 \\
\hline Phylloderma stenops & $\mathrm{I}(\mathrm{F}, \mathrm{N})$ & 0.31 & & 44203 \\
\hline Phyllostomus elongatus & $\mathrm{I}(\mathrm{F}, \mathrm{N})$ & 0.31 & & 44204 \\
\hline Phyllostomus hastatus & $\mathrm{I}(\mathrm{F}, \mathrm{N})$ & 2.19 & & $44206-44211$ \\
\hline Platyrrhinus incarum & $\mathrm{F}(\mathrm{I}, \mathrm{N})$ & 1.25 & 0.26 & $44212-44215,44477$ \\
\hline Platyrrhinus infuscus & $\mathrm{F}(\mathrm{I}, \mathrm{N})$ & 0.63 & & 44216,44217 \\
\hline Rhinophylla pumilio & $\mathrm{F}(\mathrm{I}, \mathrm{N})$ & 0.31 & & 44218 \\
\hline Sturnira sp. & $\mathrm{F}(\mathrm{I}, \mathrm{N})$ & 0.31 & & \\
\hline Trachops cirrhosus ${ }^{a}$ & $C(I, F)$ & 0.31 & 0.26 & 44219,44478 \\
\hline Uroderma bilobatum & $\mathrm{F}(\mathrm{I}, \mathrm{N})$ & 0.63 & 0.26 & $44220,44221,44479$ \\
\hline Vampyressa thyone & $\mathrm{F}(\mathrm{I}, \mathrm{N})$ & 0.31 & & 44222 \\
\hline \multicolumn{5}{|l|}{ Molossidae } \\
\hline Eumops cf. delticus ${ }^{a, b}$ & I & 0.31 & 0.26 & 44156,44455 \\
\hline Molossops temminckii ${ }^{a, b}$ & I & & 0.26 & 44456 \\
\hline Molossus molossus & I & & & 44457 \\
\hline \multicolumn{5}{|l|}{ Vespertilionidae } \\
\hline Myotis albescens & I & & 0.26 & 44480 \\
\hline Myotis nigricans & I & & 0.26 & 44481 \\
\hline Myotis simus & I & 0.31 & & 44223 \\
\hline TOTAL & & 21.88 & 11.26 & \\
\hline
\end{tabular}


dwellings or abandoned buildings as diurnal roosts (Eger 2008, Barquez \& Díaz 2015).

Species accumulation.- The accumulation curve predicted 44 species for the wet season $(a=2.20, b=0.05, a / b=44)$, that is, 19 species more than those recorded in the mist nets. Whereas for the dry season 36 species were predicted $(a=1.09, b=0.03, a / b=$ 36.33); 20 more than those recorded in the mist nets (Fig. 3). Both estimates satisfactorily fitted on the Clench model $\left(r_{\text {wet }}=99.83 \%\right.$, $r_{d r y}=99.74 \%$ ). In the wet season, we recorded $55.55 \%$ (25 species) of the estimated richness by the Clench model; while for the dry season, only $47.10 \%$ (16 species) of the total of estimated richness.
Relative abundance.- The greatest abundance occurred during the wet season with 25 recorded species (21.88 ind/ NN), where Carollia perspicillata (4.69 ind/NN), Glossophaga soricina (2.50 ind/NN), and Phyllostomus hastatus (2.19 ind/ $\mathrm{NN}$ ) were the most abundant species. During the dry season, the species richness and relative abundance were unexpectedly low (11.26 ind/NN), only 16 species were recorded. In this season, Artibeus obscurus (3.58 ind/NN), A. planirostris (2.30 ind/NN), and $C$. perspicillata (1.28 ind/NN) were the most abundant species. In general, C. perspicillata (5.97 ind/NN) and $A$. planirostris $(5.46$ ind/NN) were the most abundant in the study area (Table 1$)$.

Table 2. External and cranial measurements of Eumops cf. delticus and Molossops temminckii. Measurements are in millimeters and ordered as it follows, above: mean \pm standard deviation (number of specimens), and below the range. Sex: $\mathrm{m}=$ male $\mathrm{f}=$ female.

\begin{tabular}{|c|c|c|c|c|c|}
\hline \multirow{2}{*}{ Measurements } & \multicolumn{3}{|c|}{ Eumops cf. delticus } & \multicolumn{2}{|c|}{ Molossops temminckii } \\
\hline & $\begin{array}{l}\operatorname{Diaz}(2011) \\
\text { (f) }\end{array}$ & $\underset{(\mathrm{m})}{\operatorname{MUSM} 44156}$ & $\underset{\text { (f) }}{\operatorname{MUSM}} 44455$ & Bárquez et al. (1999) & $\underset{\text { (m) }}{\operatorname{MUSM} 44456}$ \\
\hline Total length & 110.00 & 101.00 & 105.00 & $\begin{array}{c}76.50 \pm 5.01(33) \\
60.00-84.00\end{array}$ & 72.00 \\
\hline Tail length & 45.00 & 33.00 & 39.00 & $\begin{array}{c}27.80 \pm 3.41(32) \\
21.0-34.00\end{array}$ & 25.00 \\
\hline Hind foot length & 10.00 & 9.00 & 7.00 & & 6.50 \\
\hline Ear length & 22.00 & 19.00 & 22.50 & & 11.00 \\
\hline Forearm length & 47.68 & 47.40 & 49.30 & & 31.30 \\
\hline Greatest skull length & 18.38 & 18.27 & 18.86 & $\begin{array}{c}13.40 \pm 0.32(40) \\
12.70-14.10\end{array}$ & 14.15 \\
\hline Condylobasal length & & 17.34 & 18.09 & $\begin{array}{c}13.00 \pm 0.39(42) \\
12.10-13.80\end{array}$ & 13.72 \\
\hline Condyle-incisive length & 18.11 & 18.17 & 18.69 & & 14.08 \\
\hline Condyle-canine length & & 17.13 & 17.57 & & 13.47 \\
\hline Postorbital constriction & 4.42 & 4.22 & 4.28 & $\begin{array}{c}3.70 \pm 0.16(46) \\
3.40-4.10\end{array}$ & 4.07 \\
\hline Braincase width & 8.78 & 8.80 & 8.97 & $\begin{array}{l}7.10 \pm 0.18(40) \\
\quad 6.80-7.60\end{array}$ & 7.68 \\
\hline Zygomatic width & 11.08 & 11.32 & 11.69 & $8.80 \pm 0.25(19)$ & 9.68 \\
\hline Mastoid width & 10.17 & 9.83 & 10.29 & $\begin{array}{c}8.30 \pm 0.35(38) \\
7.70-9.30\end{array}$ & 7.98 \\
\hline Palatal length & 7.13 & 7.03 & 7.09 & $\begin{array}{c}5.90 \pm 0.22(37) \\
5.50-6.40\end{array}$ & 6.37 \\
\hline Maxilar toothrow length & 6.93 & 7.40 & 7.61 & $\begin{array}{c}5.30 \pm 0.19(47) \\
4.80-5.70\end{array}$ & 5.59 \\
\hline Canine width & 4.42 & 4.98 & 5.02 & $\begin{array}{c}3.70 \pm 0.16(44) \\
3.40-4.10\end{array}$ & 3.94 \\
\hline M1 width & & 7.46 & 7.32 & & 6.00 \\
\hline M2 width & 7.67 & 8.19 & 7.94 & & 6.42 \\
\hline M3 width & & 8.6 & 8.31 & $\begin{array}{c}6.40 \pm 0.21(45) \\
\quad 6.00-6.80\end{array}$ & 6.82 \\
\hline Braincase height & & 6.7 & 7.32 & & 5.40 \\
\hline Palatal width & & 4.42 & 4.70 & & 3.71 \\
\hline Foramen magnum width & & 5.26 & 5.76 & & 4.28 \\
\hline Mandibular length & 13.18 & 13.07 & 13.46 & $\begin{array}{c}10.10 \pm 0.30(37) \\
9.50-10.80\end{array}$ & 10.05 \\
\hline Mandible height & & 1.74 & 1.69 & & 1.48 \\
\hline Mandibular toothrow length & 7.79 & 8.17 & 8.78 & $\begin{array}{l}5.80 \pm 0.21(41) \\
5.40-6.30\end{array}$ & 6.28 \\
\hline
\end{tabular}


The frugivorous bats were the best represented trophic guild, in wet $(58.11 \%, \mathrm{RA}=13.44 \mathrm{ind} / \mathrm{NN})$ and dry season $(84.44 \%$, $\mathrm{RA}=9.72$ ind/NN), followed by the insectivorous guild (wet season: $22.97 \%, \mathrm{RA}=4.06$ ind/NN; dry season: $11.11 \%, \mathrm{RA}=$ 1.02 ind/NN). Whereas, the nectarivorous (wet season: $16.22 \%$, $\mathrm{RA}=3.75$ ind $/ \mathrm{NN}$; dry season: $2.22 \%, \mathrm{RA}=0.26 \mathrm{ind} / \mathrm{NN}$ ) and carnivorous guild (wet season: $1.35 \%, \mathrm{RA}=0.31$ ind $/ \mathrm{NN}$; dry season: $2.22 \%$; $\mathrm{RA}=0.26$ ind $/ \mathrm{NN}$ ) fluctuated in abundance. Desmodus rotundus, the only hematophagous bat, was recorded in the wet season $(1.35 \%, \mathrm{RA}=0.31 \mathrm{ind} / \mathrm{NN})$ (Table 1$)$.

Similarity.- Purús shared more similarities in bat species with Cusco Amazónico (40 shared species, distance: $350 \mathrm{~km}$ ) and Parque Nacional Manu (50 shared species, distance: 270 $\mathrm{km})$. The northern localities form a different cluster with low similarities (Fig. 4). Mantel test showed that the similarity indexes among pairs of localities and geographical distance had a low correlation $(\mathrm{R}=0.473$, $\mathrm{p}<0.01$, Fig. 4$)$.

\section{Discussion}

Our study is the first on bat diversity from La Novia river and the second assessment for the Purús province. We increased the list of bats for Purús from 56 to 60 species, which included two new records for the Ucayali department. The first report for Purús was conducted in the Balta community, at $60 \mathrm{~km} \mathrm{NW}$ from the RLN, and was a compilation of several expeditions in different years with different sampling efforts (Voss \& Emmons 1996). These new records suggest that the true diversity of Purús is still unknown and more studies are needed. Purus still maintains an extensive primary forest with almost no deforestation (Mena 2016) representing a suitable place to study the diversity and assemblage patterns of the biota.

Despite having a total sampling effort of $725 \mathrm{NN}$, greater than the effort employed in other Peruvian localities (Medina et al. 2015 [ $n=43$ species, 284 NN]; Medina et al. 2016 [ $n=27$ species, $136 \mathrm{NN}]$ ), the species' accumulation curves suggested that many more species could be captured. Also, at least 24 species occurring in Balta could also be present in RLN: Rhynchonycteris naso, Saccopteryx leptura, Noctilio albiventris, Gardnerycteris crenulatum, Macrophyllum macrophyllum, Micronycteris megalotis, Trinycteris nicefori, Lophostoma brasiliense, L. carrikeri, Tonatia saurophila, Anoura caudifer, A. peruana, Choeroniscus minor, Artibeus cinereus, A. concolor, Platyrrhinus brachycephalus, Sturnira tildae, Uroderma magnirostrum, Vampyriscus bidens, Vampyrodes caraccioli, Thyroptera tricolor, Eptesicus brasiliensis, E. furinalis,

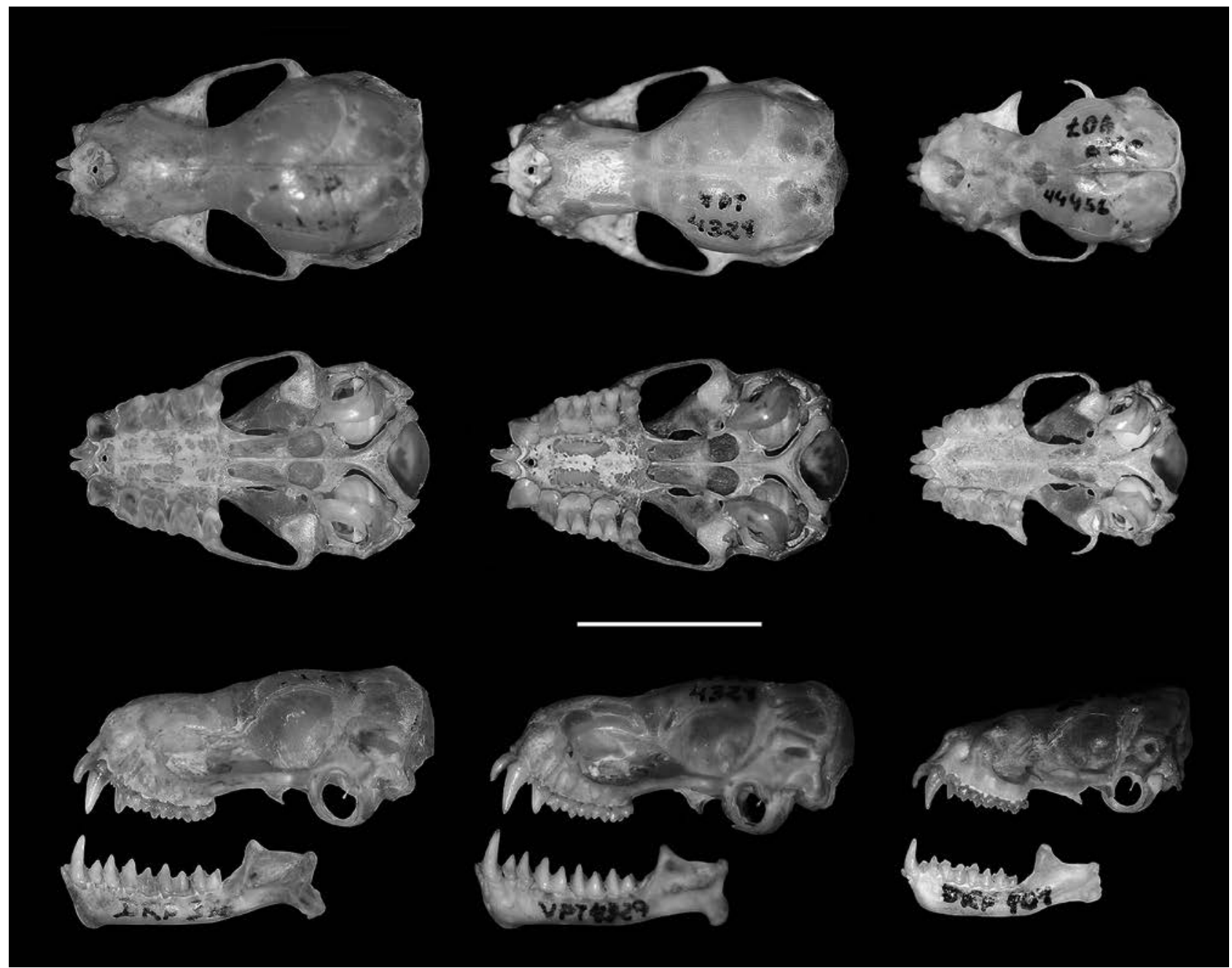

Figure 2. Skull and mandible of Eumops cf. delticus (left: MUSM 44455, female; center: MUSM 44156, male) and Molossops temminckii (right: MUSM 44456, male) recorded in La Novia river sector. Scale: $10 \mathrm{~mm}$ 
A)
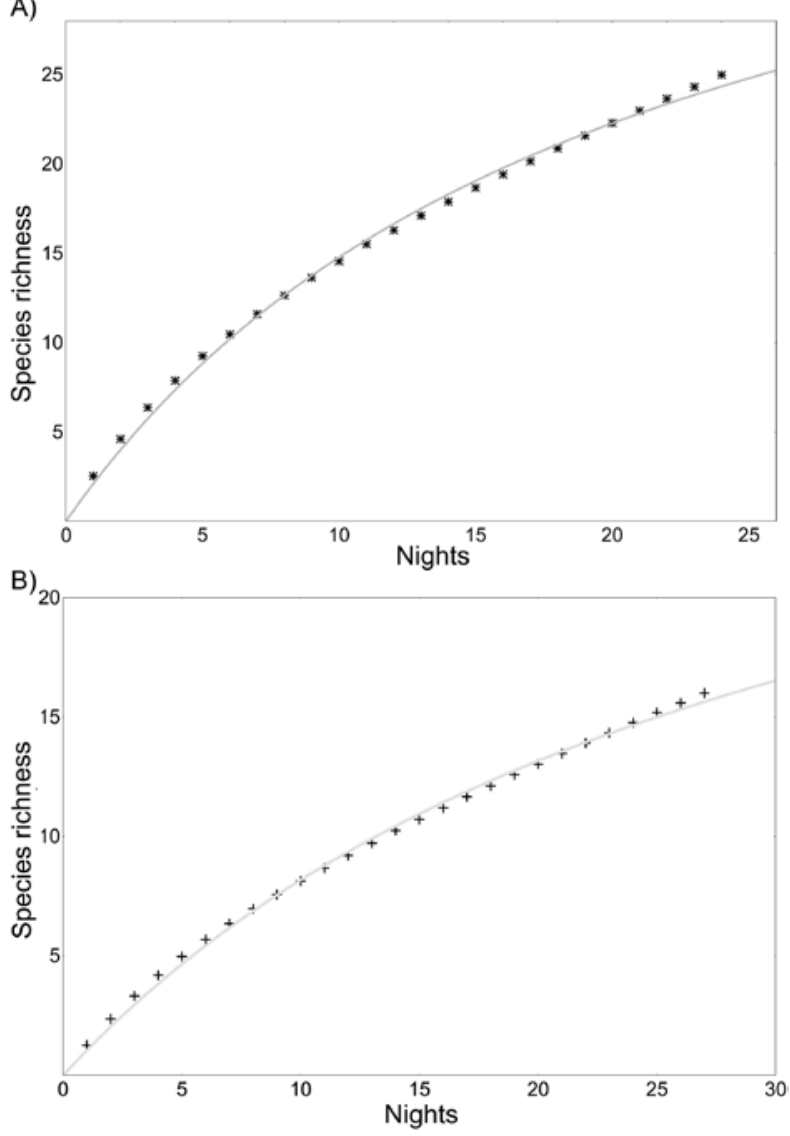

Figure 3. Accumulation curves of bats from Río La Novia Conservation Concession, in A) wet season, and B) dry season.

Lasiurus blossevillii, L. ega, Myotis riparius, Cynomops abrasus, and C. paranus (Voss \& Emmons 1996).

The family Phyllostomidae was the most abundant and rich in species (24 species), which is comparable to other reports in different localities from the Peruvian Amazon (Hice et al. 2004, Solari et al. 2006, Medina et al. 2015). This pattern probably is due to the sampling method using mist nets, which is the most effective for catching phyllostomid bats (Kingston 2016). We suggest using other methods such as ultrasound detectors to increase the number of species, especially those that fly above the canopy (Kingston 2016), and roosting exploration (Voss et al. 2016)

Our results also suggest a seasonal change in the bat community, evidenced in the composition, relative abundance of species, and percentage of the trophic guilds by season. We found fewer records in the dry season despite having a greater sampling effort (dry: $391 \mathrm{NN}$ versus wet: $334 \mathrm{NN}$ ). A similar finding was reported in Allpahuayo-Mishana (Hice et al. 2004) where the authors recorded less bat diversity in the dry season than in the wet season; however, the abundance of the RLN was much lower than Allpahuayo-Mishana. We suggest that more studies are needed to test this pattern in lowland forests (Hice et al. 2004, Klingbeil \& Willig 2010).

Several authors found that seasonality influences diet diversification and dispersion of bats for foraging food resources (as fruits or flowers), producing a remarkable variation in the

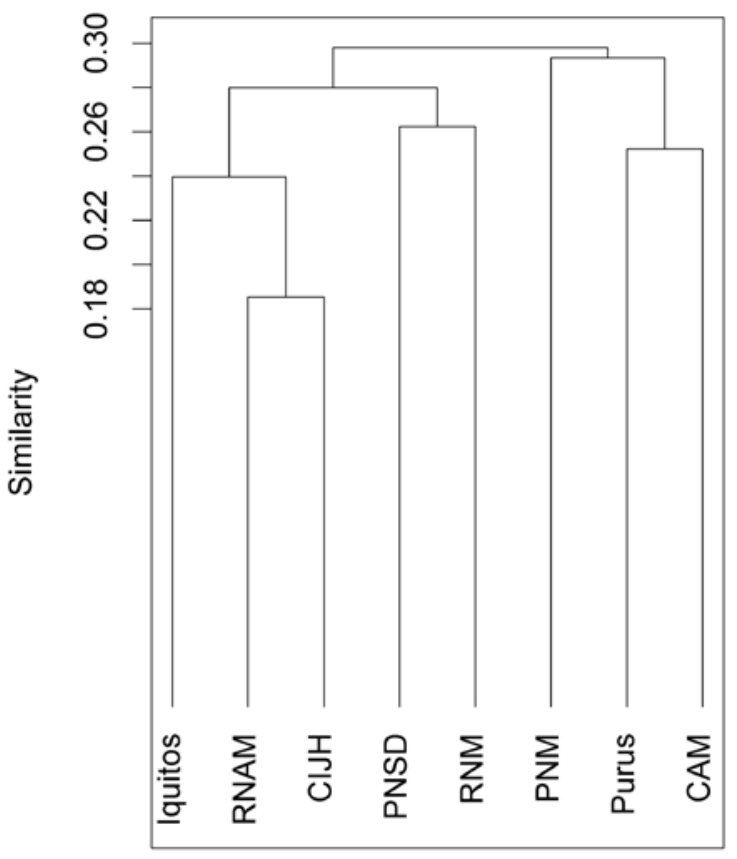

Figure 4. Similarity based on the Sorensen coefficients of eight localities of the Peruvian Amazonian. Purús: Balta and Río La Novia Conservation Concession; Iquitos: Iquitos city and surroundings.; PNSD: Parque Nacional Sierra del Divisor; PNM: Parque Nacional del Manu; RNAM: Reserva Nacional Allpahuayo-Mishana; CIJH: Centro Investigaciones Jenaro Herrera; CAM: Cusco Amazónico. See the similarity values in Table 3.

bat assemblages between seasons, for example, it is known that "opportunistic" bats can adapt to available resources in the dry season, as a survival strategy, so they are not greatly affected by seasonality (Giannini \& Kalko 2004, Klingbeil \& Willig 2010, Ramos-Pereira et al. 2010, García-García \& Santos-Moreno 2014). This last pattern has been registered for some frugivorous and nectarivorous bats as Carollia perspicillata, C. brevicauda, Glossophaga soricina, and Artibeus jamaicensis (Heithaus et al. 1975, Fleming \& Heithaus 1986, Hice et al. 2004), of which two first also were abundant in the RLN.

Pacheco et al. (2013) found that similarity index is inversely proportional to the linear geographic distance among sampled sites for montane rodents, whereas Hice et al. (2004) found the same pattern for bats in rainforests. However, our analyses found a low correlation between those variables, which might suggest bat assemblages are structured by some factor different to geographic proximity. Although, different sampling effort could explain this result, we suggest to continue investigating this pattern with more detail. -Purús has much less inventory effort than Manu or Cusco Amazónico or the northern areas as Iquitos and Allpahuayo-Mishana.

On the other hand, it is likely that bat species from Cusco Amazónico or Parque Nacional Manu (found below $500 \mathrm{~m}$ elevation) also occur in Purús, because there are no significant geographic barriers for volant mammals among those localities. This potential species occurring in Purus are: the emballonurids 
Diclidurus albus, Peropteryx kappleri, P. leucoptera, and Saccopteryx leptura, the phyllostomids Anoura caudifer, A. peruana, Artibeus concolor, A. cinereus, A. glaucus, A. gnomus, Choeroniscus minor, Diaemus youngi, Diphylla ecaudata, Enchisthenes hartii, Gardenycteris crenulatum, Glossophaga commissarisi, Lichonycteris degener, Lonchophylla handleyi, Lophostoma brasiliense, L. carrikeri, Macrophyllum macrophyllum, Micronycteris megalotis, Phyllostomus discolor, Sphaeronycteris toxophyllum, Sturnira magna, Sturnira tildae, Tonatia saurophila, Uroderma magnirostrum, Vampyriscus bidens, Vampyrodes caraccioli, and Vampyrum spectrum, the mormoopid Pteronotus gymnonotus, the noctilionids Noctilio albiventris, and N. leporinus, the furipterid Furipterus horrens, the thyropterids Thyroptera discifera, and T. Lavali, the molossids Cynomops abrasus, C. milleri, C. paranus, Eumops auripendulus, E. trumbulli, and Molossus rufus, and the vespertilionids Eptesicus brasiliensis, Lasiurus blossevillii, L. ega, and Myotis riparius (Voss \& Emmons 1996, Solari et al. 2006, Gardner 2008, Quintana et al. 2009).

Although Purús maintains still large areas of pristine forests, it is under serious threats due to a terrestrial connectivity Project between Purús (Ucayali department) and Ińapari (Madre de Dios department) (Draft Law N $\left.{ }^{\circ} 0075-2016-C R\right)$. The impact of this project is estimated to be highly negative for local residents and biodiversity, it will generate newer environmental problems and social risks for Ucayali department, as is happening in Madre de Dios department due to the construction of the Interoceanic highway: land use change, illegal logging and hunting, invasion of uncontacted indigenous territory and social problems (Naughton-Treves 2004, Pieck 2013, Aguilar-Amuchastegui et al. 2014, Goldstein 2015). The construction of roadways and other infrastructure was proposed to be highly damaging to biodiversity in many countries (Spellerberg 1998, Laurance et al. 2009, Benítez-López et al. 2010, Daigle 2010).

Conservation measures based on research and the implementation of biodiversity monitoring stations in this region are necessary and should include the participation of local populations and stakeholders to ensure that conservation is not considered an "obstacle" but a way of progress.

\section{Acknowledgments}

We thank World Wildlife Fund (WWF Perú) for the Fieldwork Travel Grants. We also thank Maribel Taco, Rocío Bardales, Carlos Ruelas, Mercedes Molina, Lisset Gómez, Pedro Huanca, and the MABOSINFRON personnel for their participation in the fieldwork; José Luis Mena for his support in this study, and Ruben M. Barquez for the confirmation of Eumops cf. delticus; finally, the Ministerio de Agricultura y Riego (MINAGRI) for the research permit (Resolución de Dirección General $N^{\circ}$ 0125-2015-SERFOR-DGGSPFFS).

\section{Literature cited}

ADAR. 2002. Evaluación de la fauna bajo presión de caza en los ríos Purús y Curanja, Ucayali, Perú. Reporte de la cuarta fase del Proyecto de evaluación y asesoría medio ambiental en el Río Purús.

Aguilar-Amuchastegu N., J.C. Riveros \& J.L. Forrest. 2014. Identifying areas of deforestation risk for REDD+ using a species modeling tool. Carbon Balance and Management 9:1-10. doi: http://dx.doi.org/10.1186/s13021-014-0010-5

Angulo S.R. \& M.M. Diaz. 2004. Nuevos registros de Sphaeronycteris toxophyllum para la Cuenca Amazónica de Perú. Mastozoología Neotropical 11(2):233-236
Ascorra C.F., D.L. Gorchov \& F. Cornejo. 1992. The bats from Jenaro Herrera, Loreto, Perú. Mammalia 57(4):533-552. doi: http://dx.doi.org/10.1515/mamm.1993.57.4.533

Barquez R. \& M.M. Diaz. 2015. Molossops temminckii. The IUCN Red List of Threatened Species 2015: e.T13643A22108409. doi: http://dx.doi.org/10.2305/IUCN.UK.2015-4.RLTS. T13643A22108409 (last access on 08/12/2017)

Barquez R., M.A. Mares \& J. K. Braun. 1999. The bats of Argentina. Special Publications, Museum of Texas Tech University 42:1-275.

Benítez-López A., R. Alkemade \& P.A. Verweij. 2010. The impacts of roads and other infrastructure on mammal and bird populations: A meta-analysis. Biological Conservation 143:13071316. doi: http://dx.doi.org/10.1016/j.biocon.2010.02.009

Cornejo F. 2016. Inventario florístico preliminar de la concesión para conservación "Río La Novia". In: J.L. Mena \& C. Germamá, eds.Diversidad biológica del sudeste de la Amazonía peruana: Avances en la investigación. Ediciones Nova Print S.A.C. Pp. 75-81.

Daigle P. 2010. A summary of the environmental impacts of roads, management responses, and research gaps: A literature review. BC Journal of Ecosystems and Management 10(3):65-89.

Díaz M.M. 2011. New records of bats from the northern region of the Peruvian Amazon. Zoological Research 32(2):168-178. doi: http://dx.doi.org/10.3724/SP.J.1141.2011.02168

Díaz M.M., S. Solari, L.F. Aguirre, L.M.S. Aguiar \& R.M. Barquez. 2016. Clave de identificación de los murciélagos de Sudamérica. Publicación especial $\mathrm{N}^{\circ}$ 2, PCMA (Programa de Conservación de Murciélagos de Argentina). 160pp

Eger J.L. 2008. Family Molossidae. In: A.L. Gardner, ed. Mammals of South America, Volume 1 Marsupials, Xenarthrans, Shrews, and Bats. The University of Chicago Press. Pp. 399-439.

Emmons L. \& F. Feer. 1999. Mamíferos de los bosques húmedos de América Tropical, una guía de campo. Editorial FAN. Santa Cruz de la Sierra.

Fernández-Arellano G.J. \& M.I. Torres-Vásquez. 2013. Lista actualizada de quirópteros de los Departamentos de Loreto, Ucayali y Madre de Dios (Perú). Barbastella 6(1):73-88. doi: http://dx.doi.org/10.14709/barbj.6.1.2013.10

Fleck D.W., R.S. Voss \& N.B. Simmons. 2002. Underdifferentiated taxa and sublexical categorization: an example from Matses classification of bats. Journal of Ethnobiology 22(1):61-102.

Fleming T.H. \& E.R. Heithaus. 1986. Seasonal foraging behavior of the frugivorous bat Carollia perspicillata (Chiroptera: Phyllostomidae). Journal of Mammalogy 67(4):660-671. doi: http://dx.doi.org/10.2307/1381127

Garbino G.S.T., C.C. de Aquino \& C.C. Aires. 2012. First record for the state of Rondônia and revised distribution map of Chiroderma trinitatum Goodwin, 1958 (Mammalia: Chiroptera: Phyllostomidae) in Brazil. Check List 8(2):254-257. doi: http://dx.doi.org/10.15560/8.2.254

García-García J.L. \& A. Santos-Moreno. 2014. Variación estacional en la diversidad y composición de ensambles de murciélagos filostómidos en bosques continuos y fragmentados en Los Chimalapas, Oaxaca, México. Revista Mexicana de Biodiversidad 85(1):228-241. doi: http://dx.doi. org/10.7550/rmb.36744

Gardner A.L. 2008 (ed.). Mammals of South America, Volume 1. Marsupials, xenarthrans, shrews, and bats. The University of Chicago Press, Chicago. doi: http://dx.doi.org/10.7208/ chicago/9780226282428.001.0001

Giannini N.P. \& E.K.V. Kalko. 2004. Trophic structure in a large assemblage of phyllostomid bats in Panama. Oikos 105(2):209-220. doi: http://dx.doi.org/10.1111/j.00301299.2004.12690.x

Goldstein R.E. 2015. The Triangular Traffic in Women, Plants, and Gold: Along the Interoceanic Road in Brazil, Peru, and Bolivia. PhD dissertation, medical Anthropology, University of California, Berkeley.

Heithaus E.R., T.H. Fleming \& P.L. Opler. 1975. Foraging patterns and resource utilization in seven species of bats in a seasonal tropical forest. Ecology 56(4):841-854. doi: http://dx.doi. org/10.2307/1936295 
Hice C.L., P.M. Velazco \& M.R. Willig. 2004. Bats of the Reserva Nacional Allpahuayo-Mishana, northeastern Peru, with notes on community structure. Acta Chiropterologica 6(2):319-334. doi: http://dx.doi.org/10.3161/001.006.0210

INRENA (Instituto Nacional de Recursos Naturales). 2001. Primera evaluación poblacional de pecaríes en la zona de alto PurúsUcayali. Dirección General Forestal y de Fauna Silvestre. Lima, Perú.

Jiménez-Velaverde A. \& J. Hortal. 2003. Las curvas de acumulación de especies y la necesidad de evaluar la calidad de los inventarios biológicos. Revista Ibérica de Aracnología 8:151-161.

Kingston T. 2016. Bats. In: T.H. Larsen, ed. Core Standardized Methods for Rapid Biological Field Assessment. Conservation International, Arlington, VA, Pp. 59-82.

Klingbeil B.T. \& M.R. Willig. 2010. Seasonal differences in population-, ensemble- and community-level responses of bats to landscape structure in Amazonia. Oikos 119(10):1654-1664. doi: http://dx.doi.org/10.1111/j.1600-0706.2010.18328.x

Laurance W., M. Goosem \& S.G.W. Laurance. 2009. Impacts of roads and linear clearings on tropical forests. Trends in Ecology \& Evolution 24(12):659-669. doi: http://dx.doi. org/10.1016/j.tree.2009.06.009

Leite R., H. Beck \& P.M. Velazco. 2003. Mamíferos terrestres y arbóreos de la selva baja de la Amazonía peruana: Entre los ríos Manu y Alto Purús. In: R. Leite, N. Pitman \& P. Alvarez, eds. Alto Purús, Biodiversidad, Conservación y Manejo. Center for Tropical Conservation. Impreso Gráfica S.A. Pp. 109-122.

Lleellish M., J. Amanzo, Y. Hooker \& S. Yale. 2003. Evaluación poblacional de pecaríes en la región del Alto Purús. In: R. Leite Pitman, N. Pitman, and P. Alvarez, eds. Alto Purús, Biodiversidad, Conservación y Manejo. Center for Tropical Conservation. Impreso Gráfica S.A. Pp.137-145.

Mantel N. 1967. The detection of disease clustering and a generalized regression approach. Cancer Research 27:209-220. doi: http://dx.doi.org/10.1158/0008-5472.can-16-0883

Medina C.E., E. López, K. Pino, A. Pari \& H. Zeballos. 2015. Biodiversidad de la Zona Reservada Sierra del Divisor (Perú): una visión desde los mamíferos pequeños. Revista Peruana de Biología 22(2):199-212. doi: http://dx.doi.org/10.15381/ rpb.v22i2.11354

Medina C.E., K. Pino, A. Pari, G. Llerena, H. Zeballos \& E. López. 2016. Mammalian diversity in the savanna from Peru, with three new addictions from country. Papéis Avulsos de Zoologia 56(2):9-26. doi: http://dx.doi.org/10.11606/00311049.2016.56.02

Medina C.E., H.T. Zamora, H. Zeballos, A. Pari, K. Pino \& W. Delgado. 2012. Primer registro de Eumops patagonicus y ampliación del rango de distribución geográfica de E. hansae, en el sur de Perú. Mastozoología Neotropical 19:345-351.

Mena J.L. 2016. Los bosques de la Amazonía del sudeste peruano. In: J.L. Mena, and C. Germaná, eds. Diversidad biológica del sudeste de la Amazonía peruana: Avances en la investigación. Ediciones Nova Print S.A.C. Pp. 14-18

Moreno C.E. 2001. Métodos para medir la biodiversidad. M\&T Manuales y Tesis SEA. 84pp.

Naughton-Treves L. 2004. Deforestation and Carbon Emissions at Tropical Frontiers: A Case Study from the Peruvian Amazon. World Development 32(1)173-190. doi: http://dx.doi. org/10.1016/j.worlddev.2003.06.014

Oksanen J. 2015. Vegan: ecological diversity. https://cran.rproject. org/web/packages/vegan/vignettes/diversity-vegan.pdf (last access on $08 / 12 / 2017$ )

Pacheco V. \& J. Amanzo. 2003. Análisis de datos de cacería en las Comunidades nativas de Pikiniki y Nuevo Belén, Río Alto Purús. In: R. Leite Pitman, N. Pitman and P. Alvarez, eds. Alto Purús, Biodiversidad, Conservación y Manejo (Center for Tropical Conservation. Impreso Gráfica S.A. Pp. 217-225.

Pacheco V. 2002. Mamíferos del Perú. In: G. Ceballos y J. Simonetti, eds. Diversidad y conservación de los mamíferos neotropicales. Conabio-UNAM. México, D.F. Pp. 503-550.

Pacheco V., E. Salas, L. Cairampoma, M. Noblecilla, H. Quintana, F. Ortiz, P. Palermo \& R. Ledesma. 2007. Contribución al conocimiento de la diversidad y conservación de los mamíferos en la cuenca del río Apurímac. Perú. Revista Peruana de Biología 14(2):169-180. doi: http://dx.doi.org/10.15381/ rpb.v14i2.1722
Pacheco V., E.Salas, C. Barriga \& E. Rengifo. 2013. Small mammal diversity in disturbed and undisturbed montane forest in the area of influence of the PERU LNG pipeline, Apurímac River watershed, Ayacucho, Peru. In: A. Alonso, F. Dallmeier, and G.P. Servat, eds. Monitoring Biodiversity, lessons from a Trans-Andean Megaproject. Smithsonian Institution Scholarly Press. Pp. 90-100.

Pacheco V., R. Cadenillas, E. Salas, C. Tello \& H. Zeballos. 2009. Diversidad y endemismo de los mamíferos del Perú. Revista Peruana de Biología 16(1):5-32. doi: http://dx.doi. org/10.15381/rpb.v16i1.111

Parlos J.A., R.M. Timm, V.J. Swier, H. Zeballos \& R.J. Baker. 2014. Evaluation of paraphyletic assemblages within Lonchophyllinae, with description of a new tribe and genus. Occasional Papers Museum of Texas Tech University 320:1-23.

Pieck S.K. 2013. Asphalt Dreams: Road Construction and Environmental Citizenship in Peru. Development and Change 44(5):1039-1063. doi: http://dx.doi.org/10.1111/ dech.12056

Pucek Z. (ed.). 1981. Keys to Vertebrates of Poland-Mammalia. Aus dem Polnischen übertragen von M. Bibrich und J. Stachurska. Warszawa (PWN-Polish Scientific Publishers). 366pp.

Quintana H., V. Pacheco \& E. Salas. 2009. Diversidad y conservación de los mamíferos de Ucayali, Perú. Ecología Aplicada 8(12):91-103. doi: http://dx.doi.org/10.21704/rea.v8i1-2.386

R Core Team. 2016. R: A language and environment for statistical computing. $r$ foundation for statistical computing, Vienna, Austria. https://www.r-project.org/

Ramos-Pereira M.J., J.T. Marques \& J.M. Palmeirim. 2010. Ecological responses of frugivorous bats to seasonal fluctuation in fruit availability in Amazonian Forests. Biotropica 42(6):680-687. doi: http://dx.doi.org/10.1111/j.1744-7429.2010.00635.x

Rengifo E.M., W. Calderón \& R. Aquino. 2013. Características de refugios de algunas especies de murciélagos en la cuenca alta del río Itaya, Loreto, Perú. Cuadernos de Investigación UNED 5(1):143-150. doi: http://dx.doi.org/10.22458/ urj.v5i1.20

Ruelas D. 2017. Diferenciación morfológica de Carollia brevicauda y C. perspicillata (Chiroptera: Phyllostomidae) de Perú y Ecuador. Revista Peruana de Biología 24(4): 363-382. doi: http://dx.doi.org/10.15381/rpb.v24i4.14063

Ruelas D., M. Taco, C. Ruelas \& V. Pacheco. 2016a. Diversidad de mamíferos medianos y grandes de la cuenca del río La Novia, Purús. In: J. L. Mena, and C. Germaná, eds. Diversidad biológica del sudeste de la Amazonía peruana: Avances en la investigación. Ediciones Nova Print S.A.C. Pp. 141-164.

Ruelas D., R. Bardales, M. Molina \& V. Pacheco. 2016b. Diversidad y abundancia de mamíferos pequeños no voladores en la Concesión de Conservación Río La Novia y comentarios sobre su distribución. In J. L. Mena, and C. Germaná, eds. Diversidad biológica del sudeste de la Amazonía peruana: Avances en la investigación. Ediciones Nova Print S.A.C. Pp. 121-140.

Sikes R.S. \& the Animal Care and Use Committee of the American Society of Mammalogists (2016) Guidelines of the American Society of Mammalogists for the use of wild mammals in research and education. Journal of Mammalogy 97(3):663-688. doi: http://dx.doi.org/10.1093/jmammal/gyw078

Solari S., V. Pacheco, L. Luna, P.M. Velazco \& B.D. Patterson. 2006. Mammals of the Manu Biosphere Reserve. Fieldiana: Zoology 110:13-22.

Spellerberg I.F. 1998. Ecological Effects of Roads and Traffic: A literature review. Global ecology and biogeography letters 7(5):317-333. doi: http://dx.doi.org/10.1046/j.1466822x.1998.00308.x

Vavrek M.J. 2015. Fossil: Palaeoecological and Palaeogeographical Analysis Tools. https://cran.r-project.org/web/packages/ fossil/fossil.pdf (last access on 08/12/2017).

Voss R.S. \& L.H. Emmons. 1996. Mammalian diversity in Neotropical lowland rainforests: A preliminary assessment. Bulletin of the American Museum of Natural History 230:1-115.

Voss R.S., D.W. Fleck, R.E. Strauss, P.M. Velazco \& N.B. Simmons. 2016. Roosting ecology of amazonian bats: evidence for guild structure in hyperdiverse mammalian communities. American Museum Novitates 3870:1-43. doi: http://dx.doi. org/10.1206/3870.1 
Wetterer A.L., M.V. Rockman \& N.B. Simmons. 2000. Phylogeny of phyllostomid bats (Mammalia: Chiroptera): data from diverse morphological systems, sex chromosomes, and restriction sites. Bulletin of the American Museum of Natural History 248:1-200. doi: http://dx.doi.org/10.1206/00030090(2000)248<0001:popbmc>2.0.co;2

Willig M.R., S.J. Presley, C.P. Bloch, C.L. Hice, S.P. Yanoviak, M.M. Díaz, L. Arias, V. Pacheco \& S.C. Weaver 2007. Phyllostomid bats of lowland Amazonia: Effects of habitat alteration on abundance. Biotropica 39(6):737-746. doi: http://dx.doi. org/10.1111/j.1744-7429.2007.00322.x
Woodman N. \& R.M. Timm. 2006. Characters and phylogenetic relationships of nectar-feeding bats, with descriptions of new Lonchophylla from western South America (Mammalia: Chiroptera: Phyllostomidae: Lonchophyllini). Proceedings of the Biological Society of Washington 119(4):437-476. doi: http://dx.doi.org/10.2988/0006-324x(2006)119[437 :capron]2.0.co;2

Appendix 1: Species recorded from the Río La Novia Conservation Concession. Family Emballonuridae: 1. Peropteryx macrotis. 2. Saccopteryx bilineata. Family Molossidae: 3. Eumops cf. delticus. 4. Molossops temminckii. Family Phyllostomidae: 5. Carollia benkeithi. 6. Carollia brevicauda. 7. Carollia perspicillata. 8. Rhinophylla pumilio 9. Glossophaga soricina. 10. Hsunycteris thomasi. 11. Lophostoma silvicolum. 12. Phylloderma stenops. 13. Phyllostomus elongatus. 14. Phyllostomus hastatus. 15. Trachops cirrhosus. 16. Desmodus rotundus. 17. Artibeus lituratus. 18. Artibeus obscurus. 19. Artibeus planirostris. 20. Chiroderma trinitatum. 21. Chiroderma villosum. 22. Dermanura anderseni. 23. Mesophylla macconnelli. 24. Platyrrhinus incarum. 25. Platyrrhinus infuscus. 26. Uroderma bilobatum 27. Vampyressa thyone. Family Vespertilionidae: 28. Myotis albescens. 29. Myotis nigricans. 30. Myotis simus.

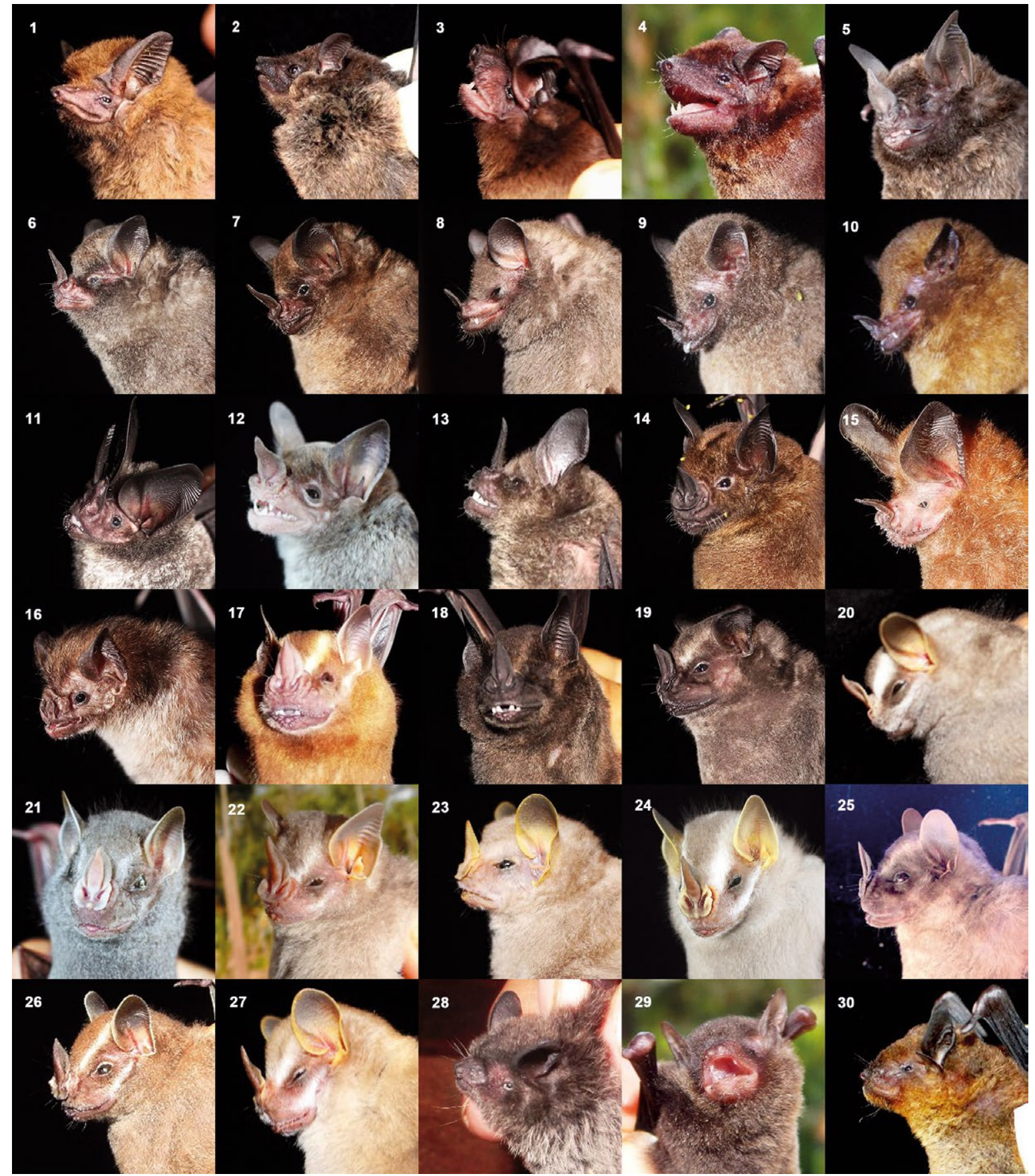

